\title{
Design of benzo-15-crown-5 azoprobe/ $\gamma$-cyclodextrin complexes for alkali metal ion recognition in water
}

\author{
Takashi Hayashita, ${ }^{\text {a* }}$ Dai Fujita, ${ }^{\text {a }}$ Takeshi Hashimoto, ${ }^{a}$ Akira Endo, ${ }^{a}$ Hui Zhao, \\ Kayo Odagiri, ${ }^{c}$ Shu Takahashi, ${ }^{c}$ Murad M. Mohamad, ${ }^{c}$ and Norio Teramae \\ ${ }^{a}$ Department of Materials and Life Sciences, Faculty of Science and Technology, Sophia \\ University, Chiyoda-ku, Tokyo 102-8554, Japan \\ ${ }^{b}$ Department of Chemistry and Biochemistry, Texas Tech University, Lubbock, Texas 79409- \\ 1062, US \\ ${ }^{c}$ Department of Chemistry, Graduate School of Science, Tohoku University, Sendai 980-8578, \\ Japan \\ E-mail: ta-hayas@sophia.ac.jp
}

Dedicated to Prof. Richard A. Bartsch on the occasion of his 70 th birthday

\begin{abstract}
Novel photosignal transduction systems of benzo-15-crown-5 (B15C5) azoprobe $/ \gamma$-cyclodextrin $(\gamma$-CyD) complexes were designed. Four B15C5 azoprobes were synthesized by azo coupling of 4'-aminobenzo-15-crown-5 with phenol (for 15C5-Az-Ph) and $N, N$-dialkylanilines (for 15C5Az-Cn). These azoprobes exhibited strong induced circular dichroism (ICD) by forming an inclusion complex with $\gamma$-CyD. Examination of the spectral responses and ${ }^{1} \mathrm{H}$ NMR analysis of the $\mathrm{B} 15 \mathrm{C} 5$ azoprobe $/ \gamma-\mathrm{CyD}$ complexes in the presence of alkali metal cations revealed that $\mathrm{K}^{+}$ binding selectively induced dimer formation of the B15C5 azoprobes inside the $\gamma$-CyD cavity, which resulted in distinct changes in their UV-vis and ICD spectra in water. The effect of alkyl chain length of 15C5-Az-Cn $(n=1,2,4) / \gamma$-CyD complexes was examined in $90 \% \mathrm{H}_{2} \mathrm{O} / 10 \%$ $\mathrm{CH}_{3} \mathrm{CN}(\mathrm{v} / \mathrm{v})$. The highest $\mathrm{K}^{+}$ion response was noted for the 15C5-Az-C2/ $\gamma$-CyD complex. The 15C5-Az-C4/ $\gamma$-CyD complex was found to show abnormally high ICD responses for $\mathrm{TMA}^{+}$and $\mathrm{Cs}^{+}$.
\end{abstract}

Keywords: Benzo-15-crown-5 ether, azoprobe, $\gamma$-cyclodextrin, alkali metal ion sensing, induced circular dichroism 


\section{Introduction}

The selective transduction of molecular recognition events into physical or chemical signals is a key concept for the design of novel supramolecular sensors. ${ }^{1}$ Cyclodextrins (CyDs) are attractive hosts for construction of supramolecular structures since water-soluble CyDs possess nanosize hydrophobic cavities which behave as a "molecular flask" to incorporate various guest molecules in water. $^{2}$ We have developed supramolecular benzo-15-crown-5 (B15C5) fluorophore/ $\gamma$ cyclodextrin $(\gamma-\mathrm{CyD})$ complexes for selective potassium $\left(\mathrm{K}^{+}\right)$ion recognition in water. ${ }^{3,4} \mathrm{Di}-$ merization of the fluorophore inside the $\gamma$-CyD was found to be selectively promoted by $\mathrm{K}^{+}$ binding, which resulted in a $\mathrm{K}^{+}$-selective pyrene dimer emission. This finding led us to design more efficient photosignal transduction systems for alkali metal ion recognition in water.
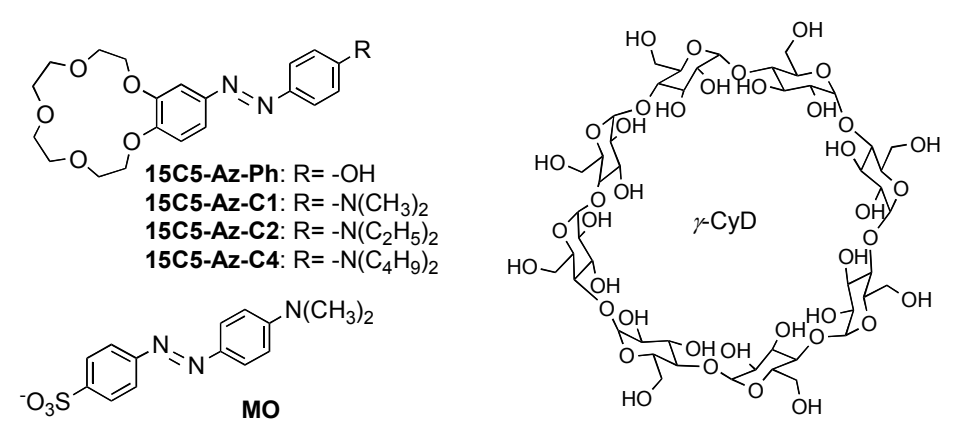

Azobenzene chromophores are known to exhibit strong induced circular dichroism (ICD) by forming an inclusion complex with CyDs based on the chiral nature of the CyD cavities. ${ }^{5,6}$ This ICD response is expected to be affected by the ion recognition events of the B15C5 modified azoprobe $/ \gamma$-CyD complexes. In addition, an exciton interaction of the azodimer may induce distinct changes in the UV-vis absorption spectra. ${ }^{7,8}$ Thus, selective UV-vis and ICD spectral changes of the $\mathrm{B} 15 \mathrm{C} 5$ azoprobe $/ \gamma-\mathrm{CyD}$ complexes are expected for alkali metal ion recognition in water.

Based upon the above concept, we designed four simple structure of $\mathrm{B} 15 \mathrm{C} 5$ azoprobes 15C5Az-Ph and 15C5-Az-Cn $(n=1,2,4)$. The novel photosignal transduction systems of the B15C5 azoprobe/ $\gamma$-CyD complexes for alkali metal ion recognition in water were assessed by ICD and UV-vis spectral characteristics as well as ${ }^{1} \mathrm{H}$ NMR analysis in relation to their supramolecular CyD complex structures.

\section{Results and Discussion}

\section{Synthesis of B15C5 azoprobes 15C5-Az-Ph and 15C5-Az-Cn}

B15C5 azoprobes 15C5-Az-Ph and 15C5-Az-Cn were synthesized by azo coupling of 4'aminobenzo-15-crown-5 with phenol (for 15C5-Az-Ph) and N,N-dialkylanilines (for 15C5-AzCn), followed by recrystallization from aqueous methanol solution or silicagel chromatography. ${ }^{9}$ 
The structures of 15C5-Az-Ph and 15C5-Az-Cn were fully confirmed by ${ }^{1} \mathrm{H}$ NMR spectra and combustion analyses.

\section{Response properties of $15 \mathrm{C5}-\mathrm{Az}-\mathrm{Ph} / \boldsymbol{\gamma}$-CyD complex}

Figure 1 shows (a) ICD and (b) UV-vis spectra of 15C5-Az-Ph $(0.050 \mathrm{mM})$ in $10.0 \mathrm{mM} \gamma$-CyD aqueous solution containing $0.10 \mathrm{M}$ tetramethylammonium chloride (TMACl) or alkali metal chlorides. In the presence of $\mathrm{TMA}^{+}$or $\mathrm{Na}^{+}$, the $15 \mathrm{C5}-\mathbf{A z}-\mathrm{Ph} / \gamma-\mathrm{CyD}$ complex exhibited no changes in its UV-vis and ICD spectra. The maximum wavelength $(370 \mathrm{~nm})$ observed in the UVvis spectrum can be assigned to a long-axis polarized $\pi-\pi^{*}$ transition of the $-\mathrm{N}=\mathrm{N}$ - group in 15C5-Az-Ph. ${ }^{10}$ When the long-axis transition of the azo group is parallel to the symmetry axis of the CyD cavity, the ICD spectrum typically exhibits a strong positive Cotton effect at the $\pi-\pi^{*}$ transition band. However, the observed positive ICD at $n-\pi^{*}$ transition $(440 \mathrm{~nm})$ suggests that 15C5-Az-Ph forms a relatively loose 1:1 complex with $\gamma$-CyD, which results in the changes of the azo group angle inside the CyD cavity or locates the $n-\pi^{*}$ transition of the azo group outside the CyD cavity. ${ }^{5}$ When $0.10 \mathrm{M} \mathrm{KCl}$ was added to this solution, the UV-vis spectrum shifted slightly to the shorter wavelength region, and the positive ICD at $\pi-\pi^{*}$ transition was intensified with decreasing ICD intensity at longer wavelengths. These spectral changes imply a selective 2:1 complex formation of $\mathbf{1 5 C 5 - A z - P h}$ with $\mathrm{K}^{+}$inside the $\gamma$-CyD cavity.

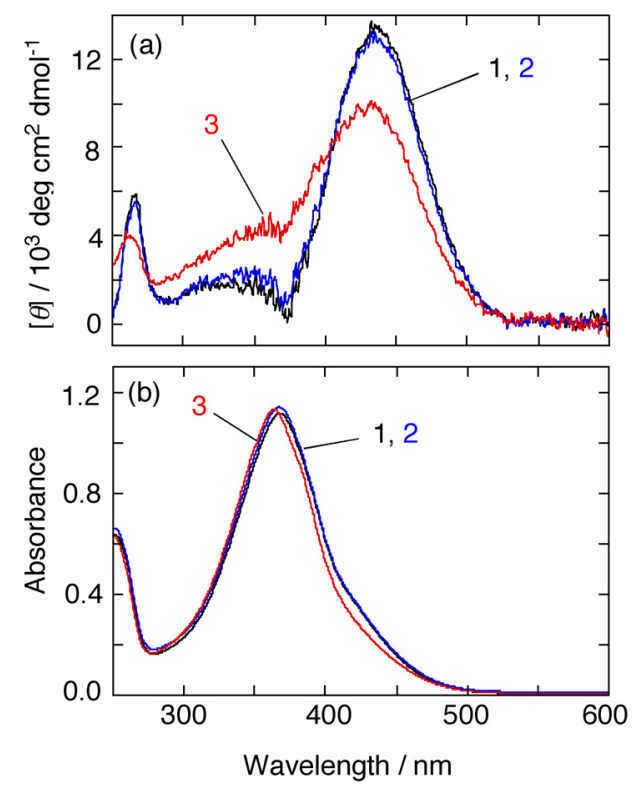

Figure 1. (a) ICD and (b) UV-vis spectra of 15C5-Az-Ph/ $\gamma$-CyD complex in $99 \% \mathrm{H}_{2} \mathrm{O} / 1 \%$ $\mathrm{CH}_{3} \mathrm{CN}(\mathrm{v} / \mathrm{v})$. [15C5-Az-Ph] $=0.050 \mathrm{mM},[\gamma-\mathrm{CyD}]=10.0 \mathrm{mM}$ in the presence of $0.10 \mathrm{M}$ (1) $\mathrm{TMACl},(2) \mathrm{NaCl}$, and (3) $\mathrm{KCl}$. 


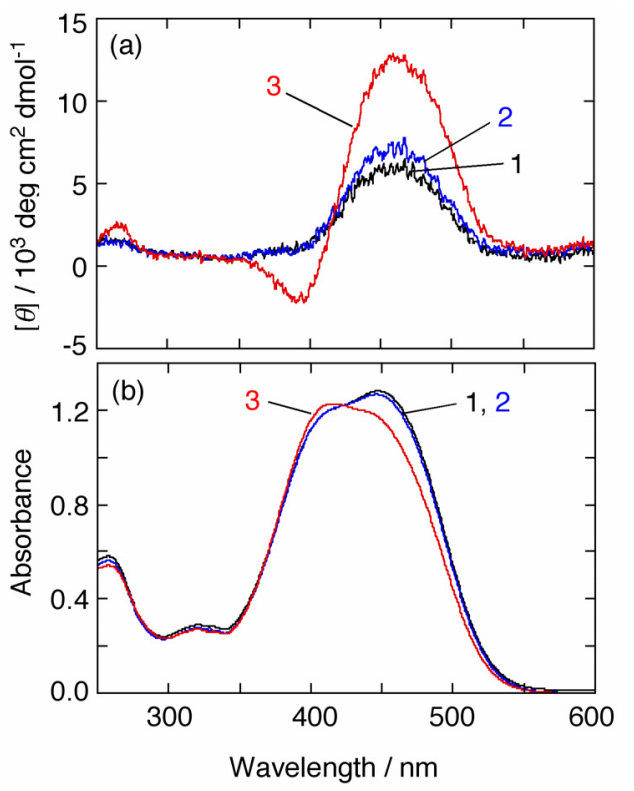

Figure 2. (a) ICD and (b) UV-vis spectra of 15C5-Az-C1/ $\gamma$-CyD complex in $99 \% \mathrm{H}_{2} \mathrm{O} / 1 \%$ $\mathrm{CH}_{3} \mathrm{CN}(\mathrm{v} / \mathrm{v})$. [15C5-Az-C1] $=0.050 \mathrm{mM},[\gamma-\mathrm{CyD}]=0.50 \mathrm{mM}$ in the presence of $0.10 \mathrm{M}$ (1) TMACl, (2) $\mathrm{NaCl}$, and (3) $\mathrm{KCl} . \mathrm{pH}=7.0$ adjusted by $5.0 \mathrm{mM} \mathrm{H}_{3} \mathrm{PO}_{4} / \mathrm{TMAOH}$ buffer. $^{13}$

\section{Response properties of $15 \mathrm{C} 5-\mathrm{Az}-\mathrm{C} 1 / \gamma-\mathrm{CyD}$ complex}

To obtain more evidence of the response mechanism of the azoprobe $/ \gamma$-CyD complex in water, 15C5-Az-C1 having an azochromophore structure similar to methyl orange (MO) was designed. Since the inclusion behavior of the $\gamma$-CyD for MO has been well studied, ${ }^{11,12}$ the spectral characteristics of $\mathbf{1 5 C 5 - A z - C 1} / \gamma-C y D$ can be directly assessed by comparing with those of the MO $/ \gamma$-CyD system. Although the 15C5-Az-C1 $/ \gamma-C y D$ complex formed a precipitate in the presence of $10.0 \mathrm{mM} \gamma-\mathrm{CyD}$, a clear solution was obtained by reducing $\gamma-\mathrm{CyD}$ concentration to $0.50 \mathrm{mM}$. This indicates that the interaction with $\gamma-\mathrm{CyD}$ of $\mathbf{1 5 C 5 - A z - C 1}$ is much stronger than that of 15C5-Az-Ph in water. The spectral responses of the 15C5-Az-C1/ $\gamma$-CyD complex are depicted in Figure 2. ${ }^{13}$ Since the $K_{\mathrm{a}}$ of protonated 15C5-Az-C1 (15C5-Az-C1 $\left.\mathrm{H}^{+}\right)$was experimentally determined to be 3.43 , the solution $\mathrm{pH}$ was adjusted to 7.0 by the addition of 5.0 $\mathrm{mM} \mathrm{H}_{3} \mathrm{PO}_{4} / \mathrm{TMAOH}$ buffer to avoid protonation. In the presence of $0.10 \mathrm{M} \mathrm{K}^{+}$, the UV-vis absorption spectrum exhibited a blue shift with reduction of molar absorptivity in the longer wavelength region (Figure $2 \mathrm{~b}$ ). This spectral response is quite similar to that of the $\mathrm{MO} / \gamma-\mathrm{CyD}$ complex when the MO dimer is formed inside the $\gamma$-CyD cavity. ${ }^{8}$ In addition, the split-type ICD spectrum observed for the 15C5-Az-C1/ $\gamma$-CyD complex in the presence of $\mathrm{K}^{+}$(Figure $2 \mathrm{a}$ ) is characteristic of the exciton interaction induced by azodimer formation inside the chiral environment. ${ }^{11}$ These results demonstrate that selective $2: 1$ complex formation of 15C5-Az-C1 with $\mathrm{K}^{+}$is taking place inside the $\gamma$-CyD cavity (Scheme 1), though the positioning of crown ether units at secondary rim side of $\gamma-\mathrm{CyD}$ in Scheme 1 has not been proved. 


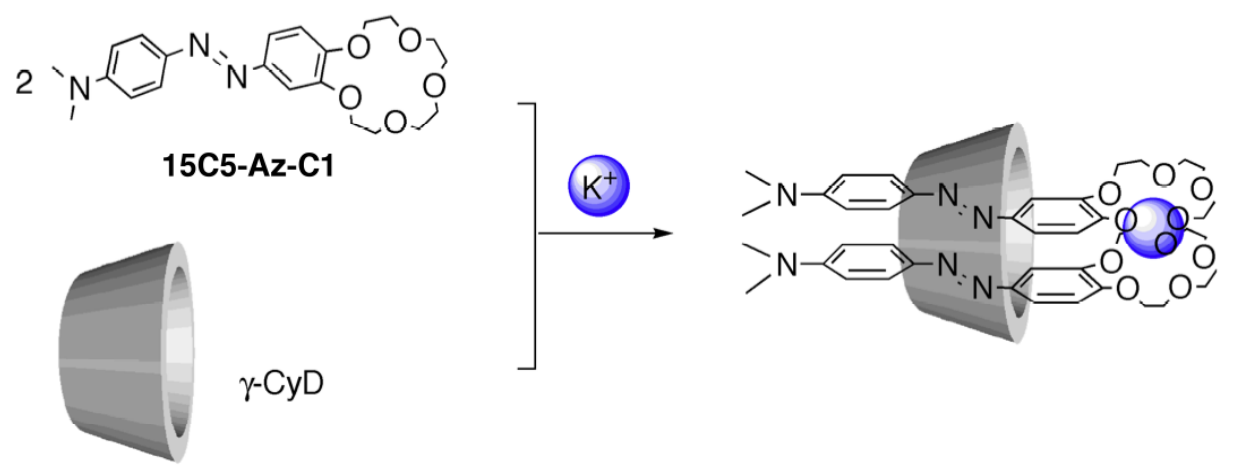

Scheme 1. Response mechanism of 15C5-Az-C1/ $/$-CyD complex sensor for $\mathrm{K}^{+}$.

\section{${ }^{1} \mathrm{H}$ NMR analysis of $15 \mathrm{C} 5-\mathrm{Az}-\mathrm{C} 1 / \mathrm{\gamma}-\mathrm{CyD}$ complex}

In order to raise the probe concentration to a $1.0 \mathrm{mM}$ level to obtain sufficient sensitivity in the ${ }^{1} \mathrm{H}$ NMR signals, the solvent system of $80 \% \mathrm{D}_{2} \mathrm{O} / 20 \% \mathrm{CD}_{3} \mathrm{CN}(\mathrm{v} / \mathrm{v})$ was used. In the presence of $0.10 \mathrm{M} \mathrm{KHCO}_{3}(\mathrm{pH}=9.8)$, it was found that the ${ }^{1} \mathrm{H}$ NMR signals of the phenyl protons in 15C5Az-C1 (1.0 mM) exhibited significant upfield shifts upon addition of $\gamma$-CyD (Figure 3b); the chemical shifts of the phenyl protons shown in Figure 3 were $\delta 7.66\left(\mathrm{H}^{\mathrm{a}}\right), 7.37\left(\mathrm{H}^{\mathrm{b}}\right), 7.26\left(\mathrm{H}^{\mathrm{c}}\right)$, $6.99\left(\mathrm{H}^{\mathrm{d}}\right), 6.76\left(\mathrm{H}^{\mathrm{e}}\right)$ in the absence of $\gamma$-CyD, and $7.38\left(\mathrm{H}^{\mathrm{a}}\right) .7 .26\left(\mathrm{H}^{\mathrm{b}}\right), 6.95\left(\mathrm{H}^{\mathrm{c}}\right), 6.93\left(\mathrm{H}^{\mathrm{d}}\right), 6.55$ $\left(\mathrm{H}^{\mathrm{e}}\right)$ in the presence of $2.0 \mathrm{mM} \gamma$-CyD. It is evident that the upfield shifts of all phenyl protons are much larger for $\mathrm{KHCO}_{3}$ system (Figure 3b) than those for $\mathrm{NaHCO}_{3}$ system (Figure 3a). When azo dyes such as MO form a 1:1 inclusion complex with CyDs, their phenyl proton signals generally shift to a lower magnetic field due to van der Waals shift and steric perturbation. ${ }^{12}$ Thus, the upfield shift observed for the 15C5-Az-C1/ $\gamma$-CyD complex can be explained by the large ring current effect of the benzene ring from the corresponding probe in the azodimer.

For the 15C5-Az-C1/ $\gamma$-CyD complex, a Job's plot analysis by ${ }^{1} \mathrm{H}$ NMR spectra was also carried out (Figure 4). The $\Delta \delta$ in Figure 4 represents the $\gamma$-CyD-induced upfield shifts of the ${ }^{1} \mathrm{H}$ NMR signals for 15C5-Az-C1. In the presence of $0.10 \mathrm{M} \mathrm{K}^{+}$, all protons exhibited upfield shifts with inflection points at $c a .0 .33$ for the molar fraction of [ $\gamma-\mathrm{CyD}] /([\gamma-\mathrm{CyD}]+[\mathbf{1 5 C 5}-\mathbf{A z}-\mathrm{C} 1])$, indicating that 15C5-Az-C1 formed a 2:1 complex with $\gamma$-CyD. These are additional lines of evidence that $\mathrm{K}^{+}$binding selectively induces dimer formation of 15C5-Az-C1 inside of the $\gamma$ CyD cavity (Scheme 1). 


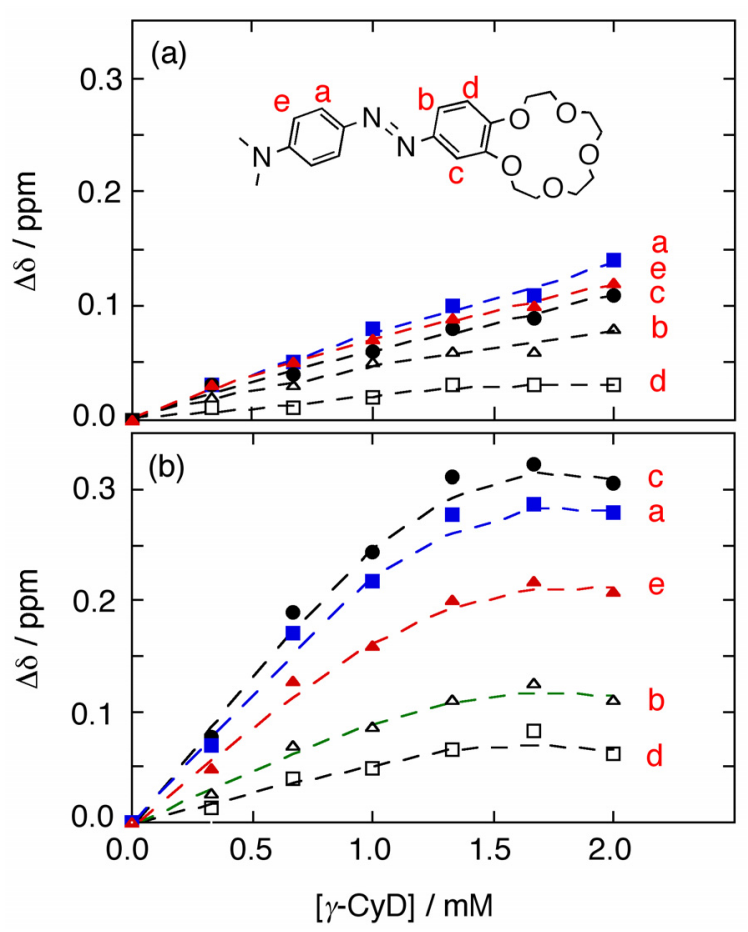

Figure 3. The $\gamma$-CyD-induced ${ }^{1} \mathrm{H}$ NMR chemical shifts of 15C5-Az-C1. [15C5-Az-C1] $=1.0$ $\mathrm{mM}$, (a) $\left[\mathrm{NaHCO}_{3}\right]=0.10 \mathrm{M}$, and (b) $\left[\mathrm{KHCO}_{3}\right]=0.10 \mathrm{M}$ in $80 \% \mathrm{D}_{2} \mathrm{O} / 20 \% \mathrm{CD}_{3} \mathrm{CN}(\mathrm{v} / \mathrm{v})$.

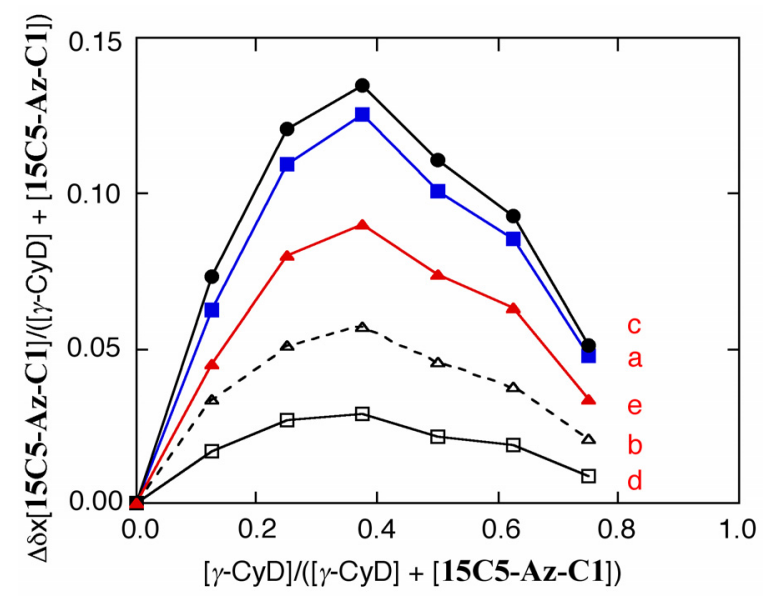

Figure 4. Job's plot of the $\gamma$-CyD-induced ${ }^{1} \mathrm{H}$ NMR chemical shifts of 15C5-Az-C1. $[\gamma-\mathrm{CyD}]+$ $[15 \mathrm{C5}-\mathbf{A z}-\mathrm{C1}]=1.0 \mathrm{mM},\left[\mathrm{KHCO}_{3}\right]=0.10 \mathrm{M}$ in $80 \% \mathrm{D}_{2} \mathrm{O} / 20 \% \mathrm{CD}_{3} \mathrm{CN}(\mathrm{v} / \mathrm{v})$.

\section{Binding efficiency and selectivity of $15 \mathrm{C} 5-\mathrm{Az}-\mathrm{C} 1 / \gamma-\mathrm{CyD}$ complex for $\mathrm{K}^{+}$}

To evaluate the binding efficiency of the $15 \mathrm{C5}-\mathrm{Az}-\mathrm{Cl} / \gamma-\mathrm{CyD}$ complex for $\mathrm{K}^{+}$, the ICD and UVvis spectral responses of the 15C5-Az-C1/ $\gamma$-CyD complex upon addition of $\mathrm{K}^{+}$in water were examined (Figure 5). The results revealed a clear crossover point in both the UV-vis and ICD spectra, indicating the presence of monomer/dimer equilibrium of 15C5-Az-C1 with the $\gamma$-CyD. 
When the changes in the ICD spectra are induced only by the 2:1 complex formation of 15C5Az-C1 with $\mathrm{K}^{+}$inside the $\gamma$-CyD cavity, the molar ellipticity $(\theta)$ is expressed by eqn. 1 :

$$
\theta=\frac{2[\mathrm{~L}]_{\mathrm{t}} J}{\left.1+\sqrt{1+8 K_{21}{ }^{\text {app }}\left[\mathrm{K}^{+}\right][\mathrm{L}]_{\mathrm{t}}}\right)} \quad J=\theta_{\mathrm{m}}+0.25 \theta_{\mathrm{d}}\left(-1+\sqrt{1+8 K_{21}{ }^{\text {aap }}\left[\mathrm{K}^{+}\right][\mathrm{L}]_{\mathrm{t}}}\right)
$$

where $[\mathrm{L}]_{\mathrm{t}}$ is the initial concentration of the probe and $\theta_{\mathrm{m}}$ and $\theta_{\mathrm{d}}$ are the molar ellipticities of the monomer and the dimer, respectively. Under constant $\gamma$-CyD concentration of $0.50 \mathrm{mM}$, the apparent 2:1 binding constant $\left(K_{21}{ }^{\text {app }}\right)$ of $15 \mathrm{C5}-\mathbf{A z}-\mathrm{C} 1$ with $\mathrm{K}^{+}$as calculated by a nonlinear program using the changes in $\theta$ at $458 \mathrm{~nm}$ was $(2.0 \pm 0.3) \times 10^{5} \mathrm{M}^{-2}$.
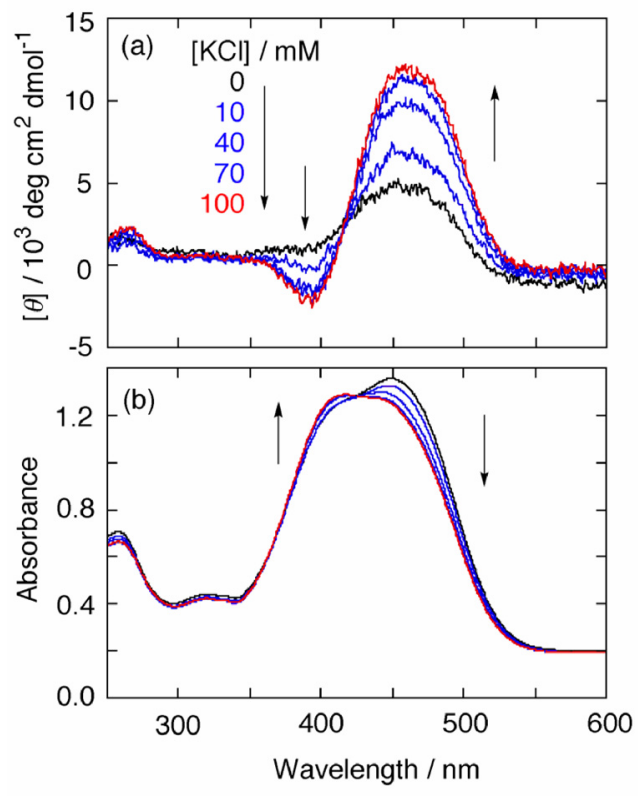

Figure 5. (a) ICD and (b) UV-vis spectra of $15 C 5-A z-C 1 / \gamma-C y D$ complex in $99 \%$ water $/ 1 \%$ $\mathrm{CH}_{3} \mathrm{CN}(\mathrm{v} / \mathrm{v})$. [15C5-Az-C1] $=0.050 \mathrm{mM},[\gamma-\mathrm{CyD}]=0.50 \mathrm{mM}, \mathrm{pH}=7.0$ adjusted by $5.0 \mathrm{mM}$ $\mathrm{H}_{3} \mathrm{PO}_{4} /$ TMAOH buffer.

Similarly the changes in the ratio of the UV-vis absorbances at $418 \mathrm{~nm}$ and $449 \mathrm{~nm}\left(A_{1} / A_{2}\right)$ can be expressed as:

$$
\frac{A_{1}}{A_{2}}=\frac{4 \frac{\varepsilon_{\mathrm{m} 1}}{\varepsilon_{\mathrm{m} 2}}+\frac{\varepsilon_{\mathrm{d} 1}}{\varepsilon_{\mathrm{d} 2}}\left(-1+\sqrt{1+8 K_{21}{ }^{\text {app }}\left[\mathrm{K}^{+}\right][\mathrm{L}]_{\mathrm{t}}}\right)}{4+\frac{\varepsilon_{\mathrm{d} 2}}{\varepsilon_{\mathrm{m} 2}}\left(-1+\sqrt{1+8 K_{21}{ }^{\text {app }}\left[\mathrm{K}^{+}\right][\mathrm{L}]_{\mathrm{t}}}\right)}
$$

where $\varepsilon_{\mathrm{m}}$ and $\varepsilon_{\mathrm{d}}$ are the molar absorptivities of monomer and dimer, respectively. From eqn. 2, the $K_{21}{ }^{\text {app }}$ value for $\mathrm{K}^{+}$was determined to be $(1.4 \pm 0.7) \times 10^{5} \mathrm{M}^{-2}$. It is worth noting that the observed $K_{21}{ }^{\text {app }}$ values of $\mathbf{1 5 C 5 - A z - C 1} / \gamma-\mathrm{CyD}$ complex are $10^{4}$-fold lower than the value reported for the $\mathrm{B} 15 \mathrm{C} 5$ fluorophore $/ \gamma$-CyD complex with $\mathrm{K}^{+}\left(3.8 \times 10^{9} \mathrm{M}^{-2}\right){ }^{3}$ This is ascribed to the difference in the binding ability of probes with $\gamma$-CyD in water. In fact, a large difference in 
the $K_{21}{ }^{\text {app }}$ value is also noted for the B15C5 fluorophores possessing different alkyl spacer chains. ${ }^{3}$ Therefore the binding efficiency is expected to be dramatically altered by proper modification of the probe structure such as changing the alkyl chain length of the dimethylamine unit in 15C5-Az-C1.

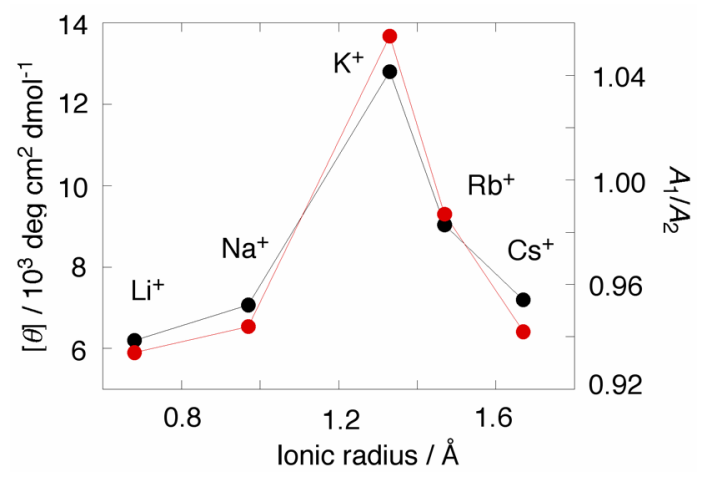

Figure 6. Dependence of $[\theta]$ at $458 \mathrm{~nm}(\bullet)$ and $\mathrm{A} 1 / \mathrm{A} 2(\bullet)$ on ionic radius of alkali metal cations. $[\mathrm{MCl}]=0.10 \mathrm{M},[\mathbf{1 5 C 5}-\mathbf{A z}-\mathbf{C 1}]=0.050 \mathrm{mM}$, and $[\gamma-\mathrm{CyD}]=0.50 \mathrm{mM}$ in $99 \% \mathrm{H}_{2} \mathrm{O} / 1 \% \mathrm{CH}_{3} \mathrm{CN}$ (v/v). $\mathrm{pH}=7.0$ adjusted by $5.0 \mathrm{mM} \mathrm{H}_{3} \mathrm{PO}_{4} / \mathrm{TMAOH}$ buffer.

The binding selectivity of the 15C5-Az-C1 $/ \gamma-C y D$ complex for alkali metal ions was assessed from the ICD and UV-vis spectra (Figure 6). Based upon the 2:1 binding ability of B15C5 moiety with $\mathrm{K}^{+3,14}$ the $\mathbf{1 5 C 5}-\mathbf{A z}-\mathbf{C 1} / \gamma-\mathrm{CyD}$ complex was found to exhibit selective response for $\mathrm{K}^{+}$over other alkali metal ions in water.

\section{Effect of alkyl chain length in 15C5-Az-Cn upon the response function}

To assess the effect of alkyl chain length, azoprobes with diethyl chains (15C5-Az-C2) and dibutyl chains (15C5-Az-C4) were additionally prepared, and their response functions as $\gamma$-CyD complexes examined. Due to the low solubility of $15 \mathrm{C} 5-\mathrm{Az}-\mathrm{C} 2$ and $15 \mathrm{C} 5-\mathrm{Az}-\mathrm{C} 4 / \gamma-\mathrm{CyD}$ complexes in water, the response behavior of all of the 15C5-Az-Cn/ $\gamma$-CyD complexes were evaluated in $90 \% \mathrm{H}_{2} \mathrm{O} / 10 \% \mathrm{CH}_{3} \mathrm{CN}(\mathrm{v} / \mathrm{v})$. The resultant $\mathrm{UV}-\mathrm{Vis}$ and ICD spectra are summarized in Figure 7. It is evident that the response function of $\mathbf{1 5 C 5 - A z - C 1} / \gamma-\mathrm{CyD}$ complex decreased significantly due to low binding ability of $\mathbf{1 5 C 5}-\mathbf{A z}-\mathbf{C 1}$ with $\gamma$-CyD in $10 \% \mathrm{CH}_{3} \mathrm{CN}$ solution. For all 15C5-Az-Cn probes, the UV-Vis spectra exhibited a $\mathrm{K}^{+}$-selective blue shift with reduction of molar absorptivity in the longer wavelength (Figures $7 b, d, f$ ), indicating a selective 2:1 complex formation of $\mathbf{1 5 C 5 - A z - C n}$ with $\mathrm{K}^{+}$. In the ICD spectra (Figures $7 \mathrm{a}, \mathrm{c}$, e), different spectral responses were observed. Thus for 15C5-Az-C1 and $15 \mathrm{C} 5-\mathrm{Az}-\mathrm{C} 2$, the $\mathrm{K}^{+}$-selective ICD response was clearly intensified by increasing the alkyl chain length from methyl to ethyl. However for 15C5-Az-C4 possessing longer dibutyl chains, abnormally large ICD responses were noted for $\mathrm{TMA}^{+}$(Figure 7e) or $\mathrm{Cs}^{+}$(data was not shown). These different responses in the $\mathrm{UV}$-Vis and ICD spectra may be ascribed to the difference in their binding mode with $\gamma$-CyD. 


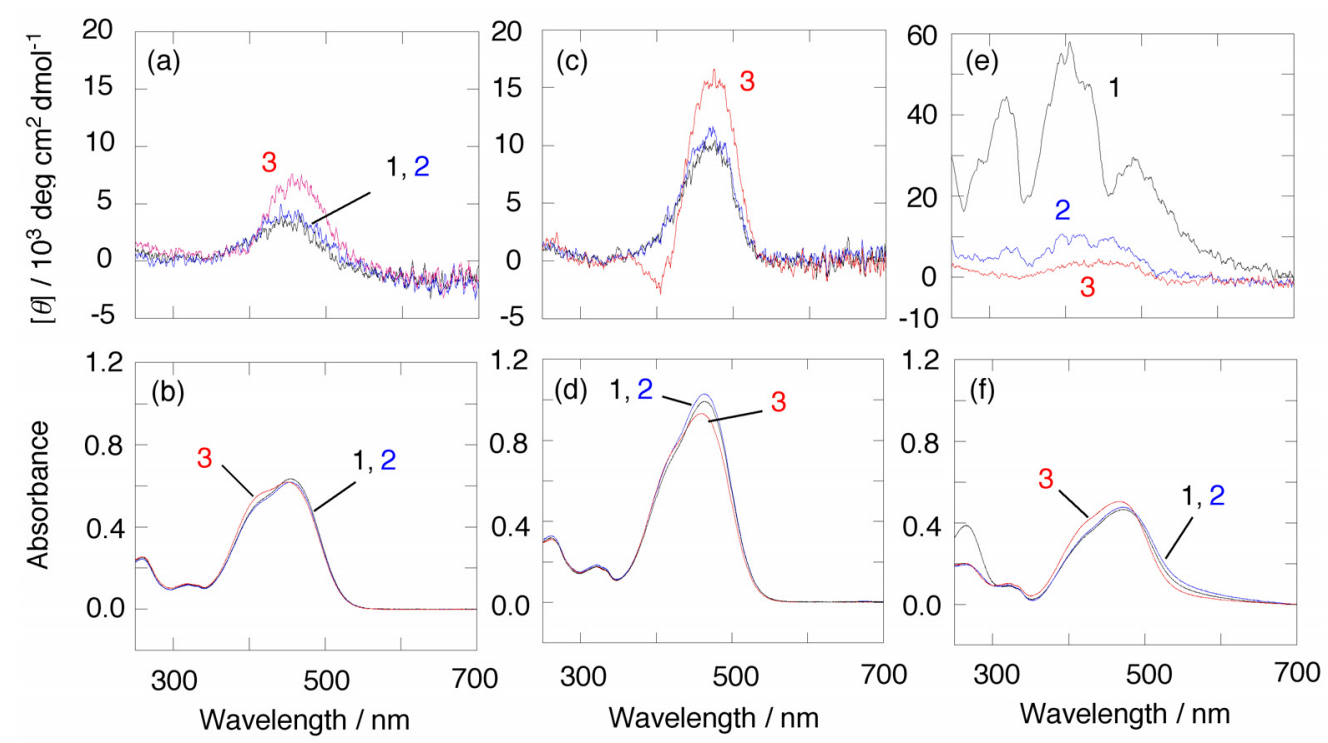

Figure 7. ICD and UV-vis spectra of $15 \mathrm{C5}-\mathbf{A z}-\mathbf{C n} / \gamma-\mathrm{CyD}$ complex in $90 \% \mathrm{H}_{2} \mathrm{O} / 10 \% \mathrm{CH}_{3} \mathrm{CN}$ $(\mathrm{v} / \mathrm{v})$. $[15 \mathrm{C5}-\mathrm{Az}-\mathrm{Cn}]=0.025 \mathrm{mM},[\gamma-\mathrm{CyD}]=2.0 \mathrm{mM}$ in the presence of $0.10 \mathrm{M}$ (1) TMACl, (2) $\mathrm{NaCl}$, and (3) KCl. ICD: (a) 15C5-Az-C1, (c) 15C5-Az-C2, (e) 15C5-Az-C4, UV-vis: (b) 15C5Az-C1, (d) 15C5-Az-C2, (f) 15C5-Az-C4.

Figure 8 shows the ICD response selectivity of $\mathbf{1 5 C 5 - A z - C n} / \gamma-C y D$ complexes for alkali metal ions. It is evident that $\mathbf{1 5 C 5}-\mathbf{A z}-\mathrm{C} 1$ and $15 \mathrm{C} 5-\mathrm{Az}-\mathrm{C} 2$ exhibited $\mathrm{K}^{+}$selectivity based on the selective dimer formation of azoprobes inside the $\gamma$-CyD. However 15C5-Az-C4 showed the abnormally large ICD response toward $\mathrm{Cs}^{+}$. For ICD response, the relative positioning of 15C5Az-Cn inside the $\gamma$-CyD strongly affects the shape of ICD spectra. As seen in Figure 7e, the strong ICD intensities for $15 \mathrm{C} 5-\mathrm{Az}-\mathrm{C} 4$ are noted not only in the $\pi-\pi^{*}$ and $\mathrm{n}-\pi^{*}$ regions of azo moiety but also in the $\pi-\pi *$ region of benzocrown ether unit. Thus the abnormal response observed for 15C5-Az-C4 may indicate the formation of different mode of CyD inclusion complex such as head-to-tail type 2:2 complex of 15C5-Az-C4 with $\gamma$-CyD (Figure 9). These are unique functions of supramomolecular $\mathrm{CyD}$ complexes based on the difference in inclusion ability of $\gamma$-CyD for 15C5-Az-Cn in the presence of alkali metal salts. 


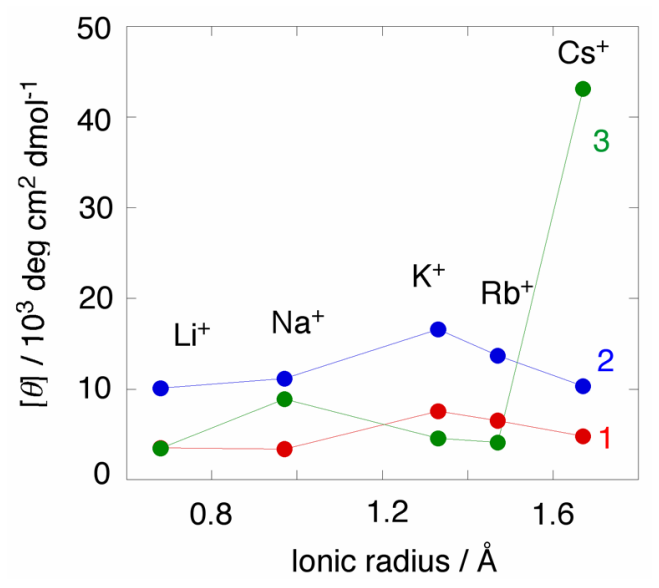

Figure 8. Dependence of ICD intensity of (1)15C5-Az-C1, (2) 15C5-Az-C2, and (3) 15C5-Az$\mathbf{C 4}$ on the ionic radius of alkali metal ions in $90 \% \mathrm{H}_{2} \mathrm{O} / 10 \% \mathrm{CH}_{3} \mathrm{CN}(\mathrm{v} / \mathrm{v})$. [15C5-Az-Cn] = $0.025 \mathrm{mM},[\gamma-\mathrm{CyD}]=2.0 \mathrm{mM}$, and $[\mathrm{MCl}]=0.10 \mathrm{M} \cdot \mathrm{pH}=7.0$ adjusted by $5.0 \mathrm{mM}$ $\mathrm{H}_{3} \mathrm{PO}_{4} / \mathrm{TMAOH}$ buffer.

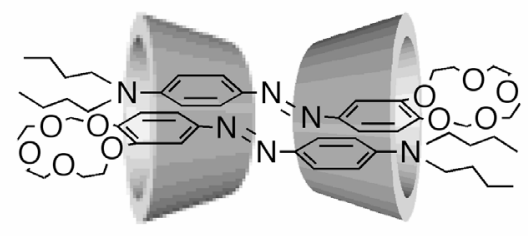

Figure 9. Prausible structure of 2:2 complex of 15C5-Az-C4 with $\gamma$-CyD.

\section{Conclusions}

In this study, novel photosignal transduction systems of B15C5 azoprobe/ $\gamma$-CyD complexes were designed. Four structures of the B15C5 azoprobes were synthesized by azo coupling 4'aminobenzo-15-crown-5 with phenol (for 15C5-Az-Ph) and N,N-dialkylaniline (for 15C5-AzCn). It was found that these azoprobes exhibited strong induced circular dichroism (ICD) by forming an inclusion complex with $\gamma$-CyD. Examination of the spectral responses and ${ }^{1} \mathrm{H}$ NMR analysis of the $\mathrm{B} 15 \mathrm{C} 5$ azoprobe $/ \gamma$-CyD complexes in the presence of alkali metal ions revealed that $\mathrm{K}^{+}$binding selectively induced dimer formation of the B15C5 azoprobes inside the $\gamma-\mathrm{CyD}$ cavity, which resulted in distinct changes in their UV-vis and ICD spectra. Thus the dynamic molecular recognition events of the B15C5 azoprobe $/ \gamma-\mathrm{CyD}$ complexes induced by $\mathrm{K}^{+}$ion binding are successfully transduced into the UV-vis and ICD spectral responses in water. The apparent 2:1 binding constants of the 15C5-Az-C1/ $\gamma$-CyD complex for $\mathrm{K}^{+}$determined by ICD and UV-vis analyses were $(2.0 \pm 0.3) \times 10^{5} \mathrm{M}^{-2}$ and $(1.4 \pm 0.7) \times 10^{5} \mathrm{M}^{-2}$, respectively. To assess the effect of alkyl chain length in 15C5-Az-Cn $(n=1,2,4)$ as $\gamma$-CyD complex, the response functions for alkali metal ions were examined in $90 \% \mathrm{H}_{2} \mathrm{O} / 10 \% \mathrm{CH}_{3} \mathrm{CN}(\mathrm{v} / \mathrm{v})$. The highest $\mathrm{K}^{+}$ 
ion response was noted for 15C5-Az-C2/ $\gamma$-CyD complex. For 15C5-Az-C4/ $\gamma$-CyD complex, abnormally large ICD responses were observed for $\mathrm{TMA}^{+}$and $\mathrm{Cs}^{+}$. These results demonstrate that the binding efficiency can be tuned by proper modification of the azoprobe structure. The present photosignal transduction systems are expected to be useful in the design of more sophisticated supramolecular CyD complexes, ${ }^{15}$ as well as CyD-based rotaxane sensors. ${ }^{16}$

\section{Experimental Section}

General. UV-vis absorption spectra were recorded on a Hitachi U-3000 spectrophotometer with a 1-cm quartz cell. The absorption spectra of each sample were obtained by subtraction of the spectra of $\gamma$-CyD solution containing $1 \%$ or $10 \% \mathrm{CH}_{3} \mathrm{CN}$ in the absence of probe. ICD spectra were obtained on a JASCO J-820 spectrophotometer with a 1-cm quartz cell. ${ }^{1} \mathrm{H}$ NMR spectra were obtained using a JEOL-GSX270 (270 MHz; JEOL DATUM).

Water was doubly distilled and deionized by a Milli-Q Labo system (Millipore) before use. The $\gamma$-CyD (Wako Pure Chemical Industries) was used without further purification. Acetonitrile (fluorescence reagent, Nakalai Tesque) was used as-received. All other solvents and reagents were obtained at the highest commercial quality and used without further purification.

\section{$N$-(2,3,5,6,8,9,11,12-Octahydro-1,4,7,10,13-benzopentaoxacyclopentadecin-15-yl)azo-4-}

phenol (15C5-Az-Ph). To $3.8 \mathrm{~mL}$ of water containing 4'-aminobenzo-15-crown-5 (0.50 g, 1.76 $\mathrm{mmol})$ and conc. $\mathrm{HCl}(0.43 \mathrm{~mL})$, sodium nitrite $(0.12 \mathrm{~g}, 1.76 \mathrm{mmol})$ in cold water $(0.7 \mathrm{~mL})$ was added and the solution was stirred for $1.0 \mathrm{~h}$ in an ice bath $\left(0-2^{\circ} \mathrm{C}\right)$. Then phenol $(0.16 \mathrm{~g}, 1.76$ $\mathrm{mmol})$ in cold water $(1.0 \mathrm{~mL})$ and aqueous $\mathrm{NaOH}$ solution $(0.50 \mathrm{M}, 5.0 \mathrm{~mL})$ were added dropwise to the solution, followed by stirring for an additional $1.0 \mathrm{~h}$. The yellow precipitate was filtered, rinsed with water, and dried in vacuo. The solid product was recrystallized from aqueous methanol to give yellow plate crystals $(0.52 \mathrm{~g}, 76 \%) .{ }^{1} \mathrm{H}$ NMR (DMSO- $\left.d_{6}, 270 \mathrm{MHz}\right) \delta 10.16(\mathrm{~s}$, $1 \mathrm{H}, \mathrm{OH}), 7.73$ (d, $J=8.6 \mathrm{~Hz}, 2 \mathrm{H}, \mathrm{ArH}), 7.47$ (dd, $J=8.6 \mathrm{~Hz}, J=2.2 \mathrm{~Hz}, 1 \mathrm{H}, \mathrm{ArH}), 7.37$ (d, $J=$ $2.2 \mathrm{~Hz}, 1 \mathrm{H}, \mathrm{ArH}), 7.10(\mathrm{~d}, J=8.6 \mathrm{~Hz}, 1 \mathrm{H}, \mathrm{ArH}), 6.90$ (d, $J=8.6 \mathrm{~Hz}, 2 \mathrm{H}, \mathrm{ArH}), 4.12$ (m, 4H, $\left.\mathrm{CH}_{2}\right), 3.79\left(\mathrm{~m}, 4 \mathrm{H}, \mathrm{CH}_{2}\right), 3.62\left(\mathrm{~m}, 8 \mathrm{H}, \mathrm{CH}_{2}\right)$. Anal. Calcd. for $\mathrm{C}_{20} \mathrm{H}_{24} \mathrm{~N}_{2} \mathrm{O}_{6} \cdot 0.2 \mathrm{H}_{2} \mathrm{O}: \mathrm{C}, 61.27 ; \mathrm{H}$, 6.22 ; N, 7.15\%. Found: C, 61.15; H, 6.31; N, 7.12\%.

N-(2,3,5,6,8,9,11,12-Octahydro-1,4,7,10,13-benzopentaoxacyclopentadecin-15-yl)azo-4dimethylaminobenzene (15C5-Az-C1). To $7.0 \mathrm{~mL}$ of water containing 4'-aminobenzo-15crown-5 (1.0 g, $3.52 \mathrm{mmol})$ and conc. $\mathrm{HCl}(0.86 \mathrm{~mL})$, sodium nitrite $(0.24 \mathrm{~g}, 3.52 \mathrm{mmol})$ in cold water $(1.4 \mathrm{~mL})$ was added and the solution was stirred for $1.0 \mathrm{~h}$ in an ice bath $\left(0-2{ }^{\circ} \mathrm{C}\right)$. Then $N$, $N$-dimethylaniline $(0.45 \mathrm{~mL}, 3.52 \mathrm{mmol})$ in acetic acid $(0.34 \mathrm{~mL})$ was added dropwise to the solution, followed by stirring for an additional $0.5 \mathrm{~h}$. The $\mathrm{pH}$ of reaction mixture was adjusted to neutral by aqueous $\mathrm{NaOH}(5.0 \mathrm{M})$, and the resulting brown precipitate was filtered, rinsed with water, and dried in vacuo. The solid was recrystallized from aqueous methanol to give brown plate crystals $(0.44 \mathrm{~g}, 30 \%) .{ }^{1} \mathrm{H} \mathrm{NMR}\left(\mathrm{CDCl}_{3}, 270 \mathrm{MHz}\right) \delta 7.81(\mathrm{~d}, J=8.5 \mathrm{~Hz}, 2 \mathrm{H}, \mathrm{ArH}), 7.47$ 
$(\mathrm{dd}, J=8.5 \mathrm{~Hz}, J=2.6 \mathrm{~Hz}, 1 \mathrm{H}, \mathrm{ArH}), 7.43(\mathrm{~d}, J=2.6 \mathrm{~Hz}, 1 \mathrm{H}, \mathrm{ArH}), 6.93(\mathrm{~d}, J=8.5 \mathrm{~Hz}, 1 \mathrm{H}$, $\operatorname{ArH}), 6.72(\mathrm{~d}, J=8.5 \mathrm{~Hz}, 2 \mathrm{H}, \mathrm{ArH}), 4.21\left(\mathrm{~m}, 4 \mathrm{H}, \mathrm{CH}_{2}\right), 3.93\left(\mathrm{~m}, 4 \mathrm{H}, \mathrm{CH}_{2}\right), 3.76\left(\mathrm{~m}, 8 \mathrm{H}, \mathrm{CH}_{2}\right)$, $3.06\left(\mathrm{~s}, 6 \mathrm{H}, \mathrm{CH}_{3}\right)$. Anal. Calcd. for $\mathrm{C}_{22} \mathrm{H}_{29} \mathrm{~N}_{3} \mathrm{O}_{5}$ : C, 63.60; H, 7.04; N, 10.11\%. Found: C, 63.69; H, 7.02; N, 9.87\%.

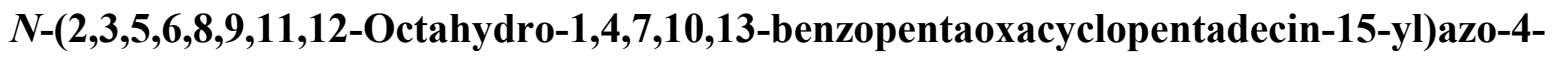
diethylaminobenzene (15C5-Az-C2). The synthesic procedure was same as that for 15C5-AzC2. Brown plate crystals $(0.33 \mathrm{~g}, 21 \%)$ recrystallized from aqueous methanol. ${ }^{1} \mathrm{H} \mathrm{NMR}\left(\mathrm{CDCl}_{3}\right.$, $270 \mathrm{MHz}) \delta 7.79(\mathrm{~d}, J=8.9 \mathrm{~Hz}, 2 \mathrm{H}, \mathrm{ArH}), 7.45(\mathrm{dd}, J=8.1 \mathrm{~Hz}, J=1.9 \mathrm{~Hz}, 1 \mathrm{H}, \mathrm{ArH}), 7.42(\mathrm{~d}, J$ $=1.9 \mathrm{~Hz}, 1 \mathrm{H}, \operatorname{ArH}), 6.92(\mathrm{~d}, J=8.1 \mathrm{~Hz}, 1 \mathrm{H}, \operatorname{ArH}), 6.69(\mathrm{~d}, J=8.9 \mathrm{~Hz}, 2 \mathrm{H}, \mathrm{ArH}), 4.20(\mathrm{~m}, 4 \mathrm{H}$, $\mathrm{CH}_{2}$ ), $3.92\left(\mathrm{~m}, 4 \mathrm{H}, \mathrm{CH}_{2}\right), 3.76\left(\mathrm{~m}, 8 \mathrm{H}, \mathrm{CH}_{2}\right), 3.43$ (q, $\left.J=7.0 \mathrm{~Hz}, 4 \mathrm{H}, \mathrm{CH}_{2}\right), 1.20$ (t, J=7.0 Hz, $6 \mathrm{H}, \mathrm{CH}_{3}$ ). Anal. Calcd. for $\mathrm{C}_{24} \mathrm{H}_{33} \mathrm{~N}_{3} \mathrm{O}_{5}$ : C, 64.99; H, 7.50; N, 9.47\%. Found: C, 64.97; H, 7.52; $\mathrm{N}, 9.41 \%$.

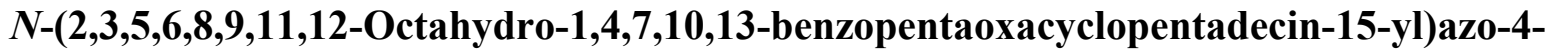
dibutylaminobenzene (15C5-Az-C4). To $2.0 \mathrm{~mL}$ of water containing 4'-aminobenzo-15-crown$5(0.25 \mathrm{~g}, 0.88 \mathrm{mmol})$ and conc. $\mathrm{HCl}(0.22 \mathrm{~mL})$, sodium nitrite $(0.067 \mathrm{~g}, 0.97 \mathrm{mmol})$ in cold water $(0.4 \mathrm{~mL})$ was added and the solution was stirred for $1.0 \mathrm{~h}$ in an ice bath $\left(0-2{ }^{\circ} \mathrm{C}\right)$. Then $N, N$-dibutylaniline $(0.18 \mathrm{~g}, 0.88 \mathrm{mmol})$ in acetone $(10.0 \mathrm{~mL})$ containing acetic acid $(0.15 \mathrm{~mL})$ was added dropwise to the solution, followed by stirring for $1.0 \mathrm{~d}$. The residue obtained after removal of the solvent was dissolved in ethyl acetate, and washed with aqueous $\mathrm{NaOH}(5.0 \mathrm{M})$ and water. The ethyl acetate layer was dried $\left(\mathrm{MgSO}_{4}\right)$, and the solvent was removed in vacuo. The resulting residue was purified by chromatography on silica gel with ethyl acetate $/ n$-hexane $(1 / 10)$ as eluent, and recrystallization from ethyl acetate/ $n$-hexane to give brown needle-like crystals $(0.07 \mathrm{~g}, 16 \%) .{ }^{1} \mathrm{H}$ NMR $\left(\mathrm{CDCl}_{3}, 270 \mathrm{MHz}\right) \delta 7.80(\mathrm{~d}, J=9.5 \mathrm{~Hz}, 2 \mathrm{H}, \mathrm{ArH}), 7.47(\mathrm{dd}, J$ $=8.0 \mathrm{~Hz}, J=2.0 \mathrm{~Hz}, 1 \mathrm{H}, \operatorname{ArH}), 7.43(\mathrm{~d}, J=2.0 \mathrm{~Hz}, 1 \mathrm{H}, \operatorname{ArH}), 6.94(\mathrm{~d}, J=8.0 \mathrm{~Hz}, 1 \mathrm{H}, \operatorname{ArH})$, $6.67(\mathrm{~d}, J=9.5 \mathrm{~Hz}, 2 \mathrm{H}, \mathrm{ArH}), 4.22\left(\mathrm{~m}, 4 \mathrm{H}, \mathrm{CH}_{2}\right), 3.93\left(\mathrm{~m}, 4 \mathrm{H}, \mathrm{CH}_{2}\right), 3.78\left(\mathrm{~m}, 8 \mathrm{H}, \mathrm{CH}_{2}\right), 3.34(\mathrm{t}$, $\left.J=8.0 \mathrm{~Hz}, 4 \mathrm{H}, \mathrm{CH}_{2}\right), 1.61\left(\mathrm{~m}, 4 \mathrm{H}, \mathrm{CH}_{2}\right), 1.38\left(\mathrm{~m}, 4 \mathrm{H}, \mathrm{CH}_{2}\right), 0.97\left(\mathrm{t}, J=7.5 \mathrm{~Hz}, 6 \mathrm{H}, \mathrm{CH}_{3}\right)$. Anal. Calcd. for $\mathrm{C}_{28} \mathrm{H}_{41} \mathrm{~N}_{3} \mathrm{O}_{5}$ : C, 67.31; H, 8.27; N, 8.41\%. Found: C, 67.60; H, 8.25; N, 8.35\%.

\section{Acknowledgements}

This work was partly supported by Grant-in-Aid for Exploratory Research (No. 21655030) from the Ministry of Education, Science, Sports and Culture of Japan, and Grant for Development of System and Technology for Advanced Measurement and Analysis from Japan Science and Technology Agency. The authors deeply acknowledge Prof. Richard A. Bartsch of Texas Tech University for his fruitful discussion and advice for the present research. The authors also thank Dr. Robert E. Hanes, Jr. of Beacon Sciences, Inc. (Austin, Texas) for organizing this special issue. 


\section{References}

1. For example: (a) Encyclopedia of Supramolecular Chemistry, Atwood, J. L. Steed, J. W. Eds., Marcel Dekker: New York, 2004. (b) Lehn, J. M. Supramolecular Chemistry: Concepts and Perspectives, VCH: Weinheim, 1995.

2. (a) Comprehensive Supramolecular Chemistry, Szejtli, J.; Osa, T. Vol. Eds. Pargamon/Elsevier: Oxford, 1996, Vol. 3. (b) Ogoshi, T.; Harada, A. Sensors 2008, 8, 4961.

3. (a) Yamauchi, A.; Hayashita, T.; Nishizawa, S.; Watanabe, M.; Teramae, N. J. Am. Chem. Soc. 1999, 121, 2319. (b) A. Yamauchi, T. Hayashita, A. Kato, S. Nishizawa, M. Watanabe, N. Teramae, Anal. Chem. 2000, 72, 5841.

4. (a) Yamauchi, A.; Hayashita, T.; Kato, A.; Teramae, T. Bull. Chem. Soc. Jpn. 2002, 75, 1527. (b) Hayashita, T.; Qing, D.; Minagawa, M.; Lee, J. C.; Ku, C. H.; Teramae, N. Chem. Commun. 2003, 2160.

5. (a) Mayer, B.; Zhang, X.; Nau, W. M.; Marconi, G. J. Am. Chem. Soc. 2001, 123, 5240; (b) Kodaka, M. J. Am. Chem. Soc. 1993, 115, 3702. (c) Kodaka, M. J. Phys. Chem. 1991, 95, 2110. (d) Kodaka, M.; Fukaya, T. Bull. Chem. Soc. Jpn. 1989, 62, 1154. (e) Harata, K.; Uedaira, H. Bull. Chem. Soc. Jpn. 1975, 48, 375. (f) Tinoco, Jr., I. Adv. Chem. Phys. 1962, 4, 113.

6. Shimpuku, R.; Ozawa, R.; Sasaki, A.; Sato, F.; Hashimoto, T.; Yamauchi, A.; Suzuki, I.; Hayashita, T. Chem. Commun. 2009, 1709.

7. (a) Kasha, M.; Rawls, H. R.; El-Bayoumi, A. Pure Appl. Chem. 1965, 11, 371. (b) Harada, N.; Nakanishi, K. Acc. Chem. Res. 1972, 5, 257.

8. Clarke, R. J.; Coates, J. H.; Lincon, S. F. Carbohydr. Res. 1984, 127, 181.

9. (a) Sato, F.; Tsukano, M.; Sakamoto, K.; Umemoto, W.; Hashimoto, T.; Hayashita, T. Bull. Chem. Soc. Jpn. 2008, 81, 1589. (b) Hayashita, T.; Kurosawa, T.; Miyata, T.; Tanaka, K.; Igawa, M. Colloid Polym. Sci. 1994, 272, 1611.

10. (a) Yoshida, N.; Yamaguchi, H.; Iwao, T.; Higashi, M. J. Chem. Soc., Perkin Trans. 2 1999, 379; (b) Yoshida, N.; Yamaguchi, H.; Higashi, M. J. Chem. Soc., Perkin Trans. 2 1994, 2507.

11. Suzuki, M.; Kajtar, M.; Szejtli, J.; Vikmon, M.; Fenyvesi, E.; Szente, L. Carbohydr. Res. 1991, 214, 25.

12. (a) Suzuki, M.; Sasaki, Y. Chem. Pharm. Bull. 1979, 27, 609. (b) Suzuki, M.; Sasaki, Y. Chem. Pharm. Bull. 1979, 27, 1343.

13. (a) Hayashita, T. Current Adv. Material Process 2003, 16, 1613. (b) Hayashita, T. J. Ion Exchange 2008, 19, 148.

14. Sato, F.; Sakamoto, K.; Umemoto, W.; Hashimoto, T. Hayashita, T. Chem. Lett. 2007, 36, 880 . 
15. (a) Fujita, N.; Ozawa, R.; Hashimoto, T.; Hayashita, T. J. Ion Exchange 2007, 18, 410. (b) Ozawa, R.; Hayashita, T.; Matsui, T.; Nakayama, C.; Yamuchi, A.; Suzuki, I. J. Incl. Phenom. Macrocycl. Chem. 2008, 60, 253. (c) Ozawa, T. Hashimoto, T.; Yamauchi, A.; Suzuki, I.; Smith, B. D.; Hayashita, T. Anal. Sci. 2008, 24, 207. (d) Kumai, M.; Kozuka, S.; Hashimoto, T.; Hayashita, T. J. Ion Exchange 2010, in press.

16. (a) I. Suzuki, I.; Yamauchi, A.; Sakashita, Y.; Hirose, K.; Miura, T.; Hayashita, T. Anal. Sci., 2007, 23, 1167. (b) Yamauchi, A.; Sakashita, Y.; Hirose, K.; Hayashita, T.; Suzuki, I. Chem. Commun. 2006, 4312. (c) Stanier, C. A.; Alderman, S. J; Claridge, T. D. W.; Anderson, H. L. Angew. Chem. Int. Ed. 2002, 41, 1769. (d) Liu, Y.; You, C.; Li, B. Chem. Eur. J. 2001, 7 , 1281. 